\title{
Продовжити життя пацієнтам з раком легень: коли недосяжне стає можливим
}

Одержано 10.04.2019

Прийнято до друку 15.04.2019

\begin{abstract}
23 березня 2019 р. у Києві відбулася Науково-практична конференція «Продовжити життя пацієнтам з раком легень: коли недосяжне стає можливим". Захід став важливим майданчиком для обміну досвідом як серед українських, так і зарубіжних фахівців. За останні роки підходи до лікування пацієнтів з раком легені значно еволюціонували, що робить надзвичайно актуальними питання діагностики та індивідуалізації терапії. Однією з найбільш очікуваних подій у рамках конференції стало обговорення сучасних терапевтичних підходів до лікування поширеного недрібноклітинного раку легені (НДРЛ) з мутацією рецептора епідермального фактора росту (epidermal growth factor receptor - EGFR) за допомогою інгібіторів тирозинкінази (tyrosine kinase inhibitor - TKI) EGFR третього покоління. Нові підходи до діагностики та лікування раку легені дозволять суттєво підвищити виживаність та покращити якість життя пацієнтів.
\end{abstract}

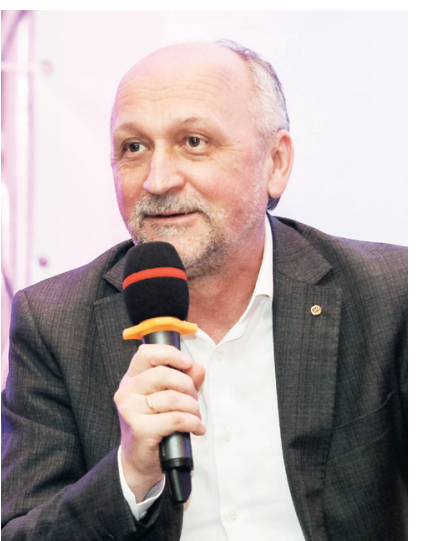

Ярослав Васильович Шпарик, кандидат медичних наук, завідувач відділення хіміотерапії Комунального некомерційного підприємства Львівської обласної ради «Львівський онкологічний регіональний лікувально-діагностичний центр», представив доповідь на тему «Сучасні підходи до лікування поширеного НДРЛ та EGFRm. Результати досліджень, що змінили стандарти», в якій докладно зупинився на ключових новітніх терапевтичних підходах.

Доповідач акцентував увагу на значних змінах, що відбулися у підходах до лікування поширеного НДРЛ за останні кілька років. Ще відносно нещодавно - до 2004 р. - НДРЛ поділявся тільки на окремі гістологічні підтипи - основні 3 яких плоскоклітинний рак та аденокарцинома. Цікаво, що за останні 20-30 років суттєво зросла частка аденокарциноми та, відповідно, зменшилася плоскоклітинного раку у загальній популяції пацієнтів із НДРЛ. Так, сьогодні на плоскоклітинний рак припадає близько $34 \%$ випадків НДРЛ, а на аденокарциному - 55\%. Слід відмітити, що при рівних умовах при використанні медикаментозної терапії зазвичай прогноз у хворих на аденокарциному кращий, ніж у тих, у кого діагностовано плоскоклітинний рак легені. У 2004 р. відкрито декілька драйверних мутацій, що, як виявилося, пов'язані з розвитком НДРЛ, а саме мутації EGFR, KRAS. На сьогодні відомо щонайменше 12 мутацій, пов'язаних із розвитком аденокарциноми, та 6 - характерних для плоскоклітинної карциноми. Виділяють чотири найбільш поширені клінічно значущі онкогенні драйверні мутації при аденокарциномі НДРЛ за результатами молекулярного аналізу, а саме мутації EGFR i BRAF та перебудови ALK i ROS1. Ці мутації впливають на механізми передачі сигналу, які регулюють клітинні функції, включно з проліферацією та апоптозом. Важливо, що у більш ніж половини хворих на аденокарциному можна виявити ту чи іншу мутацію, що, ймовірно, відповідальна за розвиток раку та може бути мішенню в ході лікувального процесу. При цьому, наприклад, мутація EGFR досить часто виникає при аденокарциномі i, навпаки, досить рідкісна у пацієнтів із плоскоклітинною карциномою. Приблизно у $30-40 \%$ аденокарцином мутації не виявляються взагалі. А найбільш поширеною мутацією є добре відома мутація KRAS - 15-25\%. Однак прицільного стандартного лікування в цьому випадку немає. Натомість другою за частотою є мутація EGFR (EGFRm), для якої роз- роблена низка препаратів таргетної терапії. Ця мутація трапляється у 10-35\% випадків НДРЛ. Частота мутації EGFR варіює між популяціями: їі частота є вищою у пацієнтів монголоїдної раси (31-41\%) порівняно з представниками європеоїдної (10-17\%), а також у некурців порівняно з курцями та у жінок порівняно із чоловіками. Доповідач підкреслив важливість пошуку мутації в гені $E G F R$ навіть у пацієнтів із плоскоклітинним раком легені, оскільки, попри значно нижчу частоту їі виявлення порівняно із аденокарциномою, вона також виникає у пацієнтів 3 плосколітинним раком легені, та її діагностування відкриває нові можливості для лікування таких хворих. Таким чином, пухлини з мутацією EGFR частіше виявляють у некурців, жінок при НДРЛ, при аденокарциномі та у пацієнтів монголоїдної раси. Також відмічають інші мутації та перебудови, які виникають значно рідше. Для лікування пацієнтів з мутаціями EGFR, ALK, ROS1, BRAF вже отримано відповідні препарати. Оскільки вже розроблено терапію для пацієнтів 3 деякими іншими мутаціями (HER2, RET, MET, MEK1, DOR2) для інших локалізацій, є надія на швидке впровадження лікування для пацієнтів із НДРЛ. Для мутацій, що лишилися неохопленими (AKT1, FGFR1, KRAS, NRAS, PIK3CA, PTEN), опрацьовуються нові лікувальні підходи.

У нормі EGFR з'єднується з епідермальним фактором росту, внаслідок чого відбувається димеризація рецептора та передача сигналу всередину клітини. Це запускає сигнальний каскад, який підтримує проліферацію клітин. Таким чином, за нормальних умов відбувається відновлення епітелію бронхів. А у випадку мутації рецептора EGFR сигнал, який активує проліферацію клітин, передається без приєднання ліганда до рецептора. Мутація у рецепторі EGFR відбувається у тирозинкіназному домені, що далі запускає сигнальний каскад всередині клітини. Таким чином, активуючі мутації в гені $E G F R$ призводять до безперервного передавання сигналу через EGFR.

Мутації при НДРЛ можуть бути первинними - їх виявляють на момент встановлення діагнозу - або вторинними, такими, що з'являються в ході терапії та є механізмом розвитку резистентності до застосовуваного препарату.

При НДРЛ активуючі мутації в гені $E G F R$ найчастіше локалізуються в екзонах з 18-го по 21-й, що кодують тирозинкіназний домен, розташований на внутрішньому боці міжклітинної мембрани між трансмембранною ділянкою та регуляторним доменом EGFR. Найчастішою активуючою мутацією є делеція у екзоні 19 або точкова мутація L858R у екзоні 21 . На них обох припадає у сумі $85 \%$ мутацій. Крім того, часто (50-60\%) трапляється вторинна мутація, що виникає під час лікування та рідко $(1,5-4 \%)$ буває у хворих до його початку, - це точкова мутація в 20-му екзоні T790M. 
Мутація Т790М являє собою основний механізм формування набутої резистентності до TKI EGFR першого та другого покоління. Ця мутація визначається більше ніж у 50-60\% пацієнтів із набутою резистентністю.

Провідними онкологічними товариствами, такими як Національна комплексна онкологічна мережа (National Comprehensive Cancer Network - NCCN), Европейське товариство медичної онкології (European Society for Medical Oncology - ESMO), Міжнародна асоціація з вивчення раку легені (International Association for the Study of Lung Cancer IASLC) та ін., для прийняття рішення про тактику лікування поширеного НДРЛ після встановлення гістологічного підтипу рекомендується проведення молекулярно-генетичного тестування. При аденокарциномі, великоклітинному раку легені обов'язковим є проведення тестування на такі біомаркери, як EGFR, ALK, ROS1, BRAF. За даними цих досліджень, у випадку EGFR ${ }^{+}, \mathrm{ALK}^{+}, \mathrm{ROS}^{+}$(приблизно 20\% пацієнтів з аденокарциномою будуть мати одну з цих мутацій) призначається таргетна терапія. Виявлення таргетної мутації та призначення відповідного лікування значно підвищують виживаність хворих на поширений НДРЛ. І тільки у тому випадку, якщо результати тестування на всі вищеперераховані показники виявляться негативними, необхідно звернути увагу на PD-L1.

Наразі існує клас препаратів, мішенню дії яких є мутований EGFR, - це TKI EGFR. Вони поєднуються у сайті зв'язування аденозинтрифосфату (АТФ) з тирозинкіназою, припиняючи таким чином передавання сигналу, спрямованого на проліферацію клітин. Нещодавно в Україні став доступний препарат третього покоління TKI EGFR Тагріссо (осимертиніб), що має унікальний механізм дії, який забезпечує селективне інгібування тирозинкінази мутованого EGFR, а також є активним при мутації резистентності T790М.

Осимертиніб є пероральним ТКІ третього покоління, створеним для таргетної терапії НДРЛ з мутацією EGFR, який при цьому володіє мінімальною активністю щодо немутованого EGFR WT, на відміну від TKI EGFR першого та другого покоління. Осимертиніб зв'язується з рецептором незворотно, що вигідно відрізняє його від TKI EGFR першого покоління, які зв'язуються зворотно. Препарат активний при активуючих мутаціях у гені $E G F R$ - делеціях у 19-му екзоні або мутації в 21-му екзоні L858R, що найчастіше спостерігаються в разі розвитку місцевопоширеного або метастатичного НДРЛ. Тагріссо, на відміну від TKI EGFR першого та другого покоління, діє при мутації вторинної резистентності Т790М у гені EGFR.

Метастази у пацієнтів з НДРЛ з мутацією EGFR часто поширюються у центральній нервовій системі (ЦНС). На момент встановлення діагнозу до 25\% пацієнтів мають метастази в ЦНС, а за час перебігу захворювання ця цифра практично подвоюється. Небезпека метастазування в головний мозок полягає у тому, що багато системних лікарських засобів не можуть проникнути через інтактний гематоенцефалічний бар'єр. Відповідно до результатів доклінічних досліджень препарат осимертиніб, на відміну від TKI EGFR першого та другого покоління, може проникати через гематоенцефалічний бар’єр і досягати високої концентрації в ЦНС. Крім того, згідно з даними клінічного дослідження III фази Тагріссо зменшує розміри метастазів у ЦНС.

Таким чином, Тагріссо як монотерапію застосовують у дорослих пацієнтів в якості терапії першої лінії місцевопоширеного або метастатичного НДРЛ з активуючими мутаціями EGFR та для лікування місцевопоширеного або метастатичного НДРЛ з позитивним статусом мутації T790М у гені EGFR.

Я.В. Шпарик навів дані низки досліджень, які демонструють процес розвитку TKI EGFR терапії. Так, у ході дослідження IPASS вивчали ефективність TKI EGFR першого покоління гефітинібу у порівнянні з хіміотерапією паклітакселом та карбоплатином при лікуванні пацієнтів з НДРЛ IIIB/IV стадії, які раніше не отримували терапії і не були активними курцями. Водночас дослідники ще не знали про важливість мутацій EGFR як таргета для лікування і тому не відбирали пацієнтів за цією ознакою. Більшість пацієнтів з НДРЛ не відповідали на терапію ТКІ EGFR гефітинібом, мішенню якої є мутований рецептор EGFR. Проте у близько $10 \%$ реєстрували швидке і значне поліпшення стану. Молекулярні механізми, що лежать в основі чутливості до гефітинібу, на той час не були відомі. За результатами дослідження постало питання: від чого залежить ефективність гефітинібу? У ході додаткових досліджень показано, що ефект лікування суттєво залежить від наявності мутації EGFR. Таким чином, вперше стало ясно, кому призначати препарати TKI EGFR.

У дослідженні EURTAC вивчали ефективність ще одного TKI EGFR ерлотинібу у порівнянні із хіміотерапією при лікуванні пацієнтів європеоїдної раси з НДРЛ IIIB/IV стадії та мутацією EGFR, в ході якого було показано, що призначення TKI EGFR цій групі пацієнтів дозволяє підвищити виживаність хворих майже удвічі. Аналогічні результати показало дослідження LUX-Lung 3, в якому вивчали ефективність TKI EGFR другого покоління афатинібу порівняно із хіміотерапією у пацієнтів європеоїдної та монголоїдної раси. При цьому було показано, що більша різниця в ефективності між афатинібом та хіміотерапією спостерігається при делеції у 19-му екзоні порівняно із точковою мутацією L858R.

Далі доповідач підсумував результати досліджень щодо ефективності TKI EGFR різних поколінь порівняно із хіміотерапією. Так, за показником частоти об'єктивної відповіді найбільшу ефективність показав препарат третього покоління TKI EGFR Тагріссо (осимертиніб). При цьому виживаність без прогресії (ВБП) для осимертинібу сягає більше 1,5 року, тоді як для препаратів першого та другого покоління цей показник здебільшого становить близько 1 року.

Цікавим є дослідження, в якому представлено ретроспективний аналіз результатів лікування пацієнтів із НДРЛ IV стадії або після рецидиву та з мутацією EGFR, яке було покликано визначити пацієнтів, для яких користь від призначення TKI EGFR була найвищою. У дослідженні взяли участь пацієнти, які прожили більше ніж 5 років від встановлення діагнозу, таких при призначенні TKI EGFR першого покоління за наявності мутації EGFR було 14,6\%. Таким чином, показано, що на підвищення виживаності може впливати мутація в 19-му екзоні гена $E G F R$, відсутність екстраторакальних метастазів та метастазів у головному мозку, а також статус некурця.

Порівнюючи частоту розвитку різних побічних ефектів при лікуванні ТКІ першого та другого покоління з аналогічними показниками для осимертинібу, доповідач відмітив значно нижчий ризик розвитку гепатотоксичності та висипів на шкірі.

У дослідженні AURA3 порівнювали ефективність осимертинібу та терапії препаратом платини і пеметрекседом за участю пацієнтів із місцевопоширеним або метастатичним НДРЛ після прогресування захворювання на першій лінії терапії TKI EGFR першого/другого покоління, зумовленим мутацією Т790М. Відповідно до отриманих результатів медіана ВБП у групі пацієнтів, які отримували осимертиніб, була більш ніж у 2 рази вищою порівняно з групою хіміотерапії.

Таким чином, осимертиніб відрізняється від TKI EGFR першого та другого покоління майже відсутнім впливом на дикий тип рецептора EGFR, що знижує вірогідність розвитку небажаних реакцій з боку шлунково-кишкового тракту та шкіри зокрема, має здатність впливати на мутацію резистентності Т790М та значно краще здатний проникати через інтактний гематоенцефалічний бар'єр. 


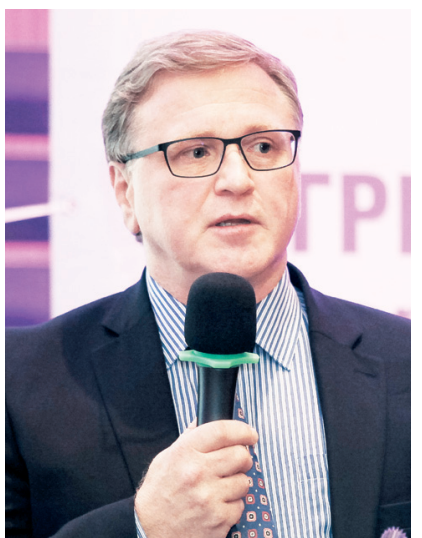

Ознайомлення з ТКI EGFR третього покоління продовжив Юрій Едуардович Руказенков, глобальний директор з клінічної розробки препаратів Тагріссо та Ipecca, «AstraZeneca», Кембридж, Великобританія, представивши доповідь, присвячену ролі осимертинібу в лікуванні НДРЛ з мутацією EGFR та програмі його клінічних досліджень.

Доповідач детально зупинився на історії створення препаратів TKI EGFR. Так, перший у класі препарат TKI EGFR - гефітиніб (Iресса) було створено у Великобританії компанією «AstraZeneca» на початку 90-х років минулого століття. Ще більше 10 років пішло на його дослідження, та нарешті у 2002 р. він став доступний пацієнтам - спочатку в Японії, а потім - в США і Європі. При розробці гефітинібу за основу було взято дані про те, що приблизно в 70\% випадків НДРЛ спостерігається оверекспресія EGFR, тоді ще не було відомо про існування мутації, що призводить до гіперактивації цього рецептора i, відповідно, про іiі значення для подальшої терапії. При цьому вивчення ролі EGFR в нормі і при патології почалося ще в 60-70-ті роки минулого століття. Було відомо, що EGFR стимулює проліферацію клітин епітелію, його оверекспресія часто спостерігається на пухлинних клітинах, та існує 7 лігандів, що активують цей рецептор, чотири з яких мають високу афінність до EGFR.

Сьогодні компанія «AstraZeneca» презентує препарат TKI EGFR вже третього покоління - Тагріссо (осимертиніб). Розробка препарату проходила в 2009-2015 pр., а запуск у 2015-2019 рр. Осимертиніб є лігандом тирозинкінази EGFR, що приєднується до рецептора у сайті зв'язування ATФ. На відміну від TKI EGFR першого та другого покоління, які зв'язуються зворотно і вимушені конкурувати з АТФ, осимертиніб, завдяки іншій просторовій структурі, зв'язується незворотно за допомогою ковалентного зв'язку, незалежно від відсутності/присутності точкової мутації T790М, яка є причиною розвитку резистентності до ТКІ EGFR першого та другого покоління. При цьому він характеризується набагато меншою спорідненістю до EGFR дикого типу, що в свою чергу дозволяє значно знизити ризик розвитку небажаних ефектів з боку шкіри та шлунково-кишкового тракту.

Інгібіторні концентрації $\mathrm{IC}_{50}$ для препаратів першого та другого і третього покоління некоректно порівнювати, оскільки перші є конкурентними інгібіторами, а ефективність залежить від співвідношення їхньої концентрації та концентрації АТФ, з яким вони конкурують за сайт зв'язування. В свою чергу осимертиніб є неконкурентним інгібітором, який ковалентно зв'язується з сайтом, тому його ефективність залежить від тривалості експозиції.

Як вже згадувалося раніше, основним механізмом розвитку резистентності до TKI EGFR першого та другого покоління $€$ поява вторинної точкової мутації Т790М, яке відбувається в $60 \%$ випадків. При цьому осимертиніб має високу активність не тільки стосовно первинних мутацій EGFR, а також T790M та низьку - щодо EGFR дикого типу (тобто немутованого), на відміну від гефітинібу і афатинібу, які мають більш низьку активність до Т790М і навпаки - більш високу активність щодо EGFR дикого типу.

Осимертиніб досить швидко пройшов доклінічний етап досліджень, продемонструвавши зменшення розмірів пухлини у ксенотрансплантатних моделях з мутаціями EGFR і T790M in vivo. Так, осимертиніб показав найкращі показники щодо зменшення пухлини в порівнянні з гефітинібом. При цьому при застосуванні осимертинібу відмічався дозозалежний ефект.

Як правило, при розробці препаратів, що застосовуються в онкології, у I фазі клінічних досліджень беруть участь не здорові добровольці, а хворі онкологічного профілю. Тому дуже важливо вже на цьому етапі правильно обрати мінімальну ефективну дозу. У програму клінічних досліджень осимертинібу входили AURA1, AURA2 і AURA3. Дослідження I фази було покликане відповісти на низку важливих питань. Серед основних цілей дослідження було оцінити безпеку, переносимість та ефективність препарату осимертиніб у пацієнтів з поширеним НДРЛ після прогресування на фоні застосування TKI EGFR. У дослідженні взяли участь більше 600 пацієнтів, які отримували препарат в дозуванні від 20 до 240 мг. Препарат був ефективний навіть у мінімальній концентрації 20 мг, максимально толерантна доза не була встановлена в ході дослідження, як і мінімально неефективна. Згідно з отриманими результатами доза 80 мг була обрана для подальших досліджень як така, що об'єднує найвищу ефективність і найкращу переносимість. У ході дослідження для деяких пацієнтів була можливість проводити подвійну біопсію з різницею 8 днів, яка показала дуже цікаві результати. Так, вже через 8 днів застосування осимертинібу в біоматеріалі, отриманому в результаті проведення біопсії, не виявляли життєздатних пухлинних клітин. Це, на думку вчених, і є матеріальною основою так званого ефекту Лазаря, який раніше часто відмічали при застосуванні TKI EGFR першого та другого покоління і який проявляється в суттєвому швидкому поліпшенні стану пацієнта після початку терапії. У роботі продемонстровано значне зменшення цільового вогнища при застосуванні осимертинібу, що дозволило у тісній співпраці з Управлінням з контролю за якістю харчових продуктів і лікарських засобів США (Food and Drug Administration - FDA) прискорити клінічні дослідження препарату.

II фаза клінічних досліджень включала дві роботи, в яких взяли участь понад 400 пацієнтів, згідно з об'єднаними результатами яких медіана ВБП становила 11 міс. Також було показано, що переносимість для цієї патології та популяції пацієнтів досить хороша.

Після клінічних досліджень I та II фази препарат Тагріссо (осимертиніб) отримав умовне схвалення від регуляторних органів США.

Потім було проведено дослідження III фази AURA3, в якому порівнювали осимертиніб як другу лінію терапії з хіміотерапією (препарат платини + пеметрексед). У дослідженні взяли участь більше 400 пацієнтів, демографічні та інші характеристики яких були добре збалансовані між групами терапії. ВБП, за оцінкою дослідника, становила 10,1 міс при застосуванні осимертинібу в порівнянні з 4,4 міс при призначенні хіміотерапії. Також було проаналізовано ВБП у пацієнтів залежно від наявності метастазів у ЦНС. Доповідач підкреслив, що на момент включення в дослідження приблизно у третини пацієнтів були виявлені вогнища метастазування в головному мозку. При цьому слід зазначити, що всіх пацієнтів не перевіряли на наявність метастазів у головному мозку, а магнітно-резонансну томографію проводили за призначенням лікаря у разі, якщо він підозрював наявність таких. ВБП пацієнтів з метастазами в ЦНС становила 8,5 міс при застосуванні осимертинібу проти 4,2 міс у групі хіміотерапії, аналогічні показники для пацієнтів без підтверджених метастазів у ЦНС сягали 10,8 і 5,6 міс відповідно. Крім того, тривалість відповіді при застосуванні осимертинібу була більшою, ніж у інших препаратів цього класу. Також препарат характеризується сприятливішим профілем безпеки порівняно $з$ хіміотерапією, легше переноситься і зручніший у прийомі. Основні побічні реакції при застосуванні осимертинібу пов'язані зі шкірою і шлунково-кишковим трактом, але вони менш виражені, ніж у препаратів більш ранніх поколінь. Також спостерігалися випадки інтерстиціальної хвороби легенів. 
Таким чином, AURA3 є першим рандомізованим дослідженням III фази для порівняння TKI EGFR третього покоління (осимертиніб) та двокомпонентної хіміотерапії на основі препаратів платини у пацієнтів з НДРЛ з позитивним статусом EGFR T790M. Осимертиніб показав статистично достовірну перевагу щодо ефективності в порівнянні з комбінацією пеметрексед + платина. Так, відношення ризиків ВБП становило 0,3 (95\% довірчий інтервал $0,23-0,41 ; \mathrm{p}<0,001)$ на користь осимертинібу. Медіана ВБП, за оцінкою дослідника, досягла 10,1 міс у групі осимертинібу у порівнянні з 4,4 міс у групі хіміотерапії. Частота об'єктивної відповіді становила $71 \%$ в групі осимертинібу проти $31 \%$ у групі хіміотерапіі.

Особливу увагу в ході аналізу об'єднаних даних досліджень II фази доповідач присвятив питанню метастазів у головному мозку. Як вже зазначено вище, хіміотерапія досить погано проникає через інтактний гематоенцефалічний бар'єр, з чим пов'язують її нижчу ефективність щодо метастазів у ЦНС при зіставленні з осимертинібом, який $є$ порівняно невеликою молекулою.

Перевагу щодо ефективності відзначено у пацієнтів як з метастазами в ЦНС, так і без них. Застосування осимертинібу було пов'язано з нижчою частотою побічних ефектів $\geqslant$ III ступеня в порівнянні з лікувальним режимом, що включає препарат платини і пеметрексед.

Таким чином, осимертиніб (Тагріссо) є новим стандартом терапії НДРЛ з підтвердженим статусом мутації Т790М в гені $E G F R$ після прогресування захворювання на першій лінії терапії TKI EGFR.

Проведено огляд даних подвійного сліпого рандомізованого дослідження III фази FLAURA, в якому порівнювали ефективність осимертинібу та TKI EGFR (гефітиніб, ерлотиніб) першого покоління у першій лінії терапії хворих на поширений НДРЛ з мутацією EGFR. Набір пацієнтів у дослідження почався у 2015 р. Усього за час дослідження було залучено більше 500 пацієнтів, які були рандомізовані на 2 групи. Перша група отримувала осимертиніб, друга - гефітиніб або ерлотиніб. В якості первинної кінцевої точки було обрано ВБП за оцінкою дослідника. Медіана ВБП для пацієнтів, що отримували осимертиніб, становила 18,9 міс, а для хворих, що отримували гефітиніб або ерлотиніб, - 10,2 міс (відношення ризиків $0,46,95 \%$ довірчий інтервал $0,37-0,57 ; \mathrm{p}<0,0001)$. При цьому осимертиніб продемонстрував перевагу у порівнянні з гефітинібом/ерлотинібом для всіх підгруп пацієнтів, які було проаналізовано. Цікаво, що пацієнти, які належать до європеодної раси, продемонстрували кращу ВБП (медіана ВБП >2 років), ніж пацієнти монголоїдної. Також проаналізовано ВБП у пацієнтів з метастазами в ЦНС і без них на момент включення у дослідження (за оцінкою дослідника). Так, медіана ВБП для пацієнтів з метастазами в ЦНС, що отримували осимертиніб, становила 15,2 міс, а для групи, яка отримувала гефітиніб або ерлотиніб, - 9,6 міс. Аналогічні показники у пацієнтів без метастазів у ЦНС, за оцінкою дослідника, сягали 19,1 і 10,9 міс відповідно. Крім того, прогресування у ЦНС відмічено у 6\% пацієнтів, які отримували осимертиніб, проти $15 \%$ пацієнтів, що одержували гефітиніб або ерлотиніб. Частота об'єктивної відповіді становила $80 \%$ для групи осимертинібу, а для групи порівняння $-76 \%$. При цьому медіана тривалості відповіді у групі пацієнтів, які застосовували осимертиніб, сягала 17,2 міс проти 8,5 міс в групі хворих, які одержували гефітиніб або ерлотиніб. Таким чином, тривалість відповіді була вдвічі більшою.

Профіль безпеки осимертинібу виявився дещо кращим порівняно з гефітинібом/ерлотинібом, зокрема, зафіксована менша кількість тяжких побічних явищ, особливо висипу. Прийом осимертинібу може мати невеликий вплив на загальну кількість тромбоцитів, що призводить до транзиторного зниження їх рівня, втім без будь-яких клінічних наслідків.
Окремо доповідач зупинився на аналізі результатів підгрупи пацієнтів з метастазами у ЦНС в дослідженні FLAURA. Так, осимертиніб продемонстрував перевагу у клінічній ефективності щодо метастазів у ЦНС у порівнянні як з хіміотерапією, так і з препаратами TKI EGFR (гефітиніб або ерлотиніб). При цьому за рік дослідження кількість метастазів у ЦНС у групі гефітинібу/ерлотинібу збільшилася з чверті до третини, а в групі осимертинібу - навпаки зменшилася. На декількох доклінічних моделях, включаючи приматів (макаки), осимертиніб продемонстрував здатність краще проникати через гематоенцефалічний бар'єр у порівнянні з усіма доступними тепер TKI EGFR.

Процес лікування при ураженнях головного мозку при поширеному НДРЛ IV стадії еволюціонував, оскільки пацієнти тепер живуть кілька років, існують навіть пацієнтирекордсмени, які живуть 14 років. При цьому, як правило, у пацієнтів-довгожителів є залишкова пухлина, яка не росте і не проліферує. Тому здатність препарату стримувати прогресування захворювання саме у головному мозку є дуже важливою як для виживаності пацієнтів, так і для забезпечення хорошої якості життя.

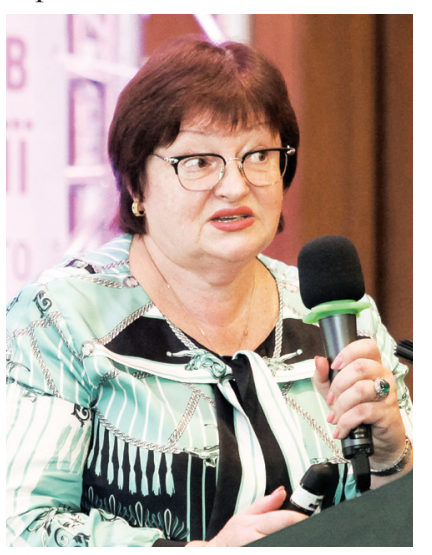

Ольга Володимирівна Пономарьова, кандидат медичних наук, доцент кафедри онкології Національної медичної академії післядипломної освіти імені П.Л. Шупика, навела приклади клінічних випадків лікування НДРЛ з мутацією EGFR.

Перший клінічний випадок: чоловік віком 68 років, курець, кинув палити 15 років тому, загальний стаж паління - 15 пачкороків. Супутня патологія цукровий діабет 2-го типу, компенсований гіпоглікемічними препаратами. У червні 2018 р. з'явилася задишка і невеликий кашель, утруднене дихання, пацієнт звернувся до терапевта, була призначена рентгенографія легень і виявлено новоутворення у верхній і середній частках правої легені - пухлина 4,5 см з ураженням лімфовузлів. При магнітно-резонансній томографії головного мозку з контрастом виявлено множинні об'ємні утворення. Проведено біопсію пухлини; за результатами гістологічного дослідження діагноз було уточнено - аденокарцинома. Молекулярно-генетичний аналіз показав наявність мутації у вигляді делеції у 19 -му екзоні EGFR, PDL-1 $\geqslant 50 \%$. Таким чином, встановлено діагноз аденокарциноми нижньої частки правої легені T2bN2M1, мутація EGFR.

Згідно з рекомендаціями NCCN при виявленні 1-3 метастазів у головному мозку проводять хірургічне втручання або стереотаксичну радіохірургію. Обговорюється проведення променевої терапії на весь головний мозок на додаток до хірургії/радіохірургії. Або виконується променева терапія на весь головний мозок: при неможливості проведення хірургії/радіохірургії чи в разі відсутності системного контролю захворювання. Останнє, як зазначила доповідач, $\epsilon$ небажаною практикою $з$ огляду на результати останніх досліджень.

У разі якщо виявлено більш ніж 3 метастази у головному мозку, показана променева терапія на весь головний мозок. Стереотаксична радіохірургія рекомендується в окремих випадках (до 10 вогнищ) при системному контролі захворювання. Хірургічне лікування показане у хворих із симптомними метастазами (з мас-ефектом) з наступною променевою терапією/радіохірургією при системному контролі захворювання. Доповідач навела результати досліджень, згідно з якими локальна терапія у вигляді хірургічного лікування в комбіна- 
ції з опроміненням всього обсягу головного мозку погіршуе віддалені результати терапії.

О.В. Пономарьова акцентувала увагу на тому, що осимертиніб демонструє істотну перевагу щодо своєї здатності проникати через гематоенцефалічний бар'єр у порівнянні з іншими TKI EGFR. Так, максимальна концентрація осимертинібу в головному мозку становить 2,8 ммоль, аналогічні показники для гефітинібу - 0,17 ммоль, а концентрації росилетинібу та афатинібу були нижчими за межу кількісного визначення. Крім того, результати дослідження FLAURA, як уже згадувалося раніше, свідчать про ефективність осимертинібу щодо метастазів у ЦНС у рамках першої лінії терапії у пацієнтів з поширеним НДРЛ і мутацією EGFR. Також результати вказують на зниження ризику прогресування захворювання у ЦНС при застосуванні осимертинібу порівняно із препаратами TKI EGFR.

Грунтуючись на наведених даних, прийнято рішення призначити пацієнтові осимертиніб. Таким чином, із серпня 2018 р. пацієнт почав отримувати осимертиніб 80 мг 1 раз на добу. Через 2 тиж відзначено істотне зменшення вираженості симптомів і суб'єктивне поліпшення самопочуття. МРТконтроль у грудні 2018 р. показав, що утворення у головному мозку, які накопичують контрастну речовину, зберігаються. Пацієнт продовжує прийом осимертинібу при хорошій якості життя.

Доповідач представила до уваги учасників конференції ще один клінічний випадок. Пацієнтка - жінка віком 76 років, супутні патології - артеріальна гіпертензія III стадії, гостре порушення мозкового кровообігу в 1999 і 2000 р., ішемічна хвороба серця, атеросклеротичний кардіосклероз. У лютому 2015 р. з'явився кашель, пацієнтка звернулася до лікаря, за результатами флюорографії було виявлено вогнищеві зміни в правій легені. Комп'ютерна томографія, проведена у квітні 2015 р., показала наявність новоутворення у нижній частці правої легені, поширення метастазів у середню частку правої легені і лімфовузли середостіння. Встановлено діагноз - аденокарцинома нижньої частки правої легені T2bN2M0 IIIA стадії.

У червні 2015 р. виконана нижня білобектомія справа. При дослідженні післяопераційного гістологічного матеріалу виявлено мутацію EGFR у вигляді делеції у 19-му екзоні. У вересні 2015 р. при контрольній комп'ютерній томографії виявлено прогресію захворювання - появу метастатичного ураження в обох легенях, плеврит справа.

3 листопада 2015 р. пацієнтка отримувала осимертиніб 80 мг 1 раз на добу. В ході лікування відзначалося мінімум побічних ефектів терапії (сухість шкіри, гіперкератоз). Висипу не виявлено. Періодично виникала нейтропенія I-II ступеня. При комп'ютерній томографії відзначалася часткова відповідь пухлини (через 6 тиж після початку терапіі) - зменшення на $57 \%$ суми контрольних вогнищ, зникнення плевриту. Стан пацієнтки був задовільний. ВБП становила 35 міс. На жаль, пацієнтка померла від захворювання, не пов'язаного з онкологічною патологією.

Таким чином, науково-практична конференція дозволила практикуючим спеціалістам значно розширити свої знання щодо новітніх таргетних терапевтичних підходів, що застосовуються для лікування пацієнтів із поширеним НДРЛ. Учасники конференції отримали вагому наукову інформацію з перших рук щодо ефективності та профілю безпеки препарату Тагріссо (осимертиніб) - незворотного TKI EGFR третього покоління - і поставити питання безпосередньо розробнику цього новітнього лікарського засобу. Важливо, що українські пацієнти з поширеним НДРЛ одними з перших отримали доступ до цієї сучасної терапії, адже в багатьох із них немає часу на очікування.
Свгенія Гончарук, фото організаторів конференціі 